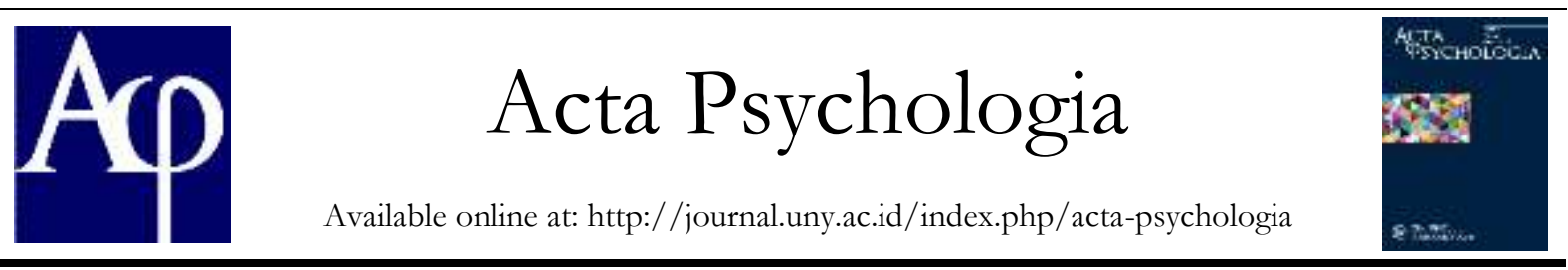

\title{
Perilaku Prososial Sebagai Prediktor Subjective Well-Being pada Sukarelawan Kelas Inspirasi Yogyakarta
}

\author{
Anik Cabyani \\ Jurusan Psikologi, Fakultas Ilmu Pendidikan, Universitas Negeri Yogyakarta; \\ Jl. Colombo No. 1 Sleman Yogyakarta, 55281 \\ ann.anik.cahyani@gmail.com
}

\begin{abstract}
Penelitian ini bertujuan untuk mengetahui perilaku prososial sebagai prediktor subjective well-being pada sukarelawan Kelas Inspirasi Yogyakarta. Penelitian ini menggunakan pendekatan kuantitatif dengan jenis penelitian korelasional. Subjek penelitian berjumlah 100 orang dengan menggunakan teknik pengambilan sampel yaitu accidental sampling. Alat pengumpulan data menggunakan skala perilaku prososial dan skala subjective well-being. Validitas dalam skala penelitian ini menggunakan validitas isi yang dilakukan oleh expert. Reliabilitas skala penelitian ini menggunakan koefisien reliabilitas Alpha Cronbach sebesar $0.93(\alpha=0,93)$ pada skala perilaku prososial dan $0.94(\alpha=0.94)$ pada skala subjective well-being. Hasil penelitian menunjukkan bahwa perilaku prososial mampu memprediksi subjective wellbeing $(\beta=0.61 ; \mathrm{p}<0.001)$. Perilaku prososial dapat memprediksi subjective well-being dengan nilai kontribusi sebesar $37 \%\left(\mathrm{R}^{2}=0.37 ; \mathrm{F}(1,98)=58.06 ; \mathrm{p}<0.001\right)$
\end{abstract}

Kata Kunci: perilaku prososial, subjective well-being, sukarelawan

\begin{abstract}
This study aims to determine prosocial behavior as a predictor of subjective well-being in Kelas Inspirasi Yogyakarta. This study uses a quantitative approach with a type of correlational research. The research subjects were 100 people using accidental sampling technique. Data collection tools used the prosocial behavior scale and subjective wellbeing scale. Validity in the scale of this study used content validity carried out by expert. Reliability in the scale of this study used Alpha Cronbach reliability coefficient of $0.93(\alpha=0.93)$ on the prosocial behavior scale and 0.94 $(\alpha=0,94)$ on the subjective well-being scale. The result of this study shows that prosocial behavior was able to predict subjective well-being $(\beta=0.61 ; \mathrm{p}<0.001)$. Prosocial behavior can predict subjective well-being with a contribution value of $37 \%\left(\mathrm{R}^{2}=0.37 ; \mathrm{F}(1,98)=58.06 ; \mathrm{p}<0.001\right)$.
\end{abstract}

Keywords: prosocial behavior, subjective well-being, volunteer

\section{Pendahuluan}

Setiap manusia akan mengalami perkembangan dalam kehidupan, yaitu pola pergerakan atau perubahan yang berkelanjutan pada rentang hidup manusia (Santrock, 2013). Salah satu masa perkembangan manusia adalah masa dewasa. Masa dewasa terdiri dari masa dewasa awal, masa dewasa madya, dan masa dewasa akhir. Masa dewasa awal terjadi di usia 21 sampai 40 tahun, masa dewasa madya terjadi di usia 41 sampai 60 tahun, sedangkan masa dewasa akhir terjadi di atas usia 60 tahun (Santrock, 2013).

Menjadi dewasa melibatkan periode transisi yang panjang dan ditandai oleh eksperimen dan eksploitasi (Santrock, 2013). Selanjutnya Santrock (2013) menjelaskan bahwa eksperimen dan eksploitasi yang dimaksudkan pada masa perkembangan dewasa adalah eksploitasi mengenai 
keinginan untuk menjadi individu seperti apa dan bagaimana gaya hidup yang diinginkan. Individu pada masa perkembangannya membutuhkan kesehatan agar dapat berkembang dengan lebih maksimal. Kesehatan individu terdiri atas kesehatan secara fisik dan psikologis.

Kesehatan yang positif ditunjukkan oleh tidak adanya penyakit fisik dan adanya kebutuhan untuk merasa baik secara psikologis atau yang disebut sebagai psychological well-being (Ryff, dalam Fakhitah \& Djamhoer, 2015). Aspinwal (dalam Ramadhani, Djunaedi, \& Sismiati, 2016) menggambarkan psycbological well-being sebagai keberfungsian psikologis yang baik dan positif. Schultz (dalam Ramadhani, Djunaedi, \& Sismiati, 2016) mengatakan bahwa individu yang memiliki psychological well-being mampu berfungsi secara positif dengan adanya arah atau tujuan yang ingin dicapai dalam hidupnya. Kemudian, individu akan melakukan evaluasi atas peristiwa-peristiwa yang dijalani dalam kehidupannya tersebut. Hasil dari evaluasi tersebut terdiri atas evaluasi kognitif dan afektif yang disebut sebagai subjective well-being (Diener, Oishi, \& Lucas, 2012).

Subjective well-being merupakan hasil evaluasi kognitif dan afektif seseorang terhadap kehidupan yang dijalaninya (Diener, Oishi, \& Lucas, 2012). Subjective wellbeing yang tinggi merupakan suatu kondisi yang ingin dicapai oleh individu (Anic \& Toncic, 2013). Hidupbukan hanya memiliki tujuan untuk hidup dalamwaktu lama, tetapi hidup dengan memiliki subjective well-being yang tinggi di dalamnya (Lomas, 2016). Diener, Oishi, dan Lucas (2012) mengatakan bahwa subjective wellbeing seorang individu dapat dikatakan tinggi apabila individu tersebut sering mengalami afek positif dan puas dalam hidupnya serta jarang mengalami afek negatif.

Berdasarkan Laporan Kebahagiaan Dunia 2018 yang dikeluarkan oleh Perserikatan Bangsa Bangsa (PBB), Indonesia berada di peringkat 96 dari 156 negara dan mengalami penurunan dari tahun sebelumnya yaitu pada peringkat 81 (Anonim, 2018). Laporan Kebahagiaan Dunia 2018 menggunakan alat ukur yang disusun berdasarkan teori subjective well-being. Hasil ini menunjukkan bahwa subjective well-being masyarakat di Indonesia perlu ditingkatkan untuk memaksimalkan dampak positif dan meminimalkan dampak negatif dari rendahnya tingkat subjective well-being.

Individu yang memiliki tingkat subjective well-being yang rendah akan mengalami dampak negatif dalam kehidupannya. Seperti yang dilansir oleh CNN Indonesia (Anonim, 2016) bahwa orang yang memiliki tingkat subjective well-being yang rendah akan memiliki kebiasaan buruk seperti pesimis, suka mengeluh, mudah iri, serta kurangnya tindakan untuk meningkatkan diri. Subjective well-being bisa didapatkan dari sumber- sumber yang mampu memberikan perasaanbahagia pada masingmasing individu.

Subjective well-being bisa didapatkan dari internal maupun eksternal manusia (Seligman, 2004). Salah satu faktor eksternal yang dapatmempengaruhi subjective well-being pada seseorang adalah kehidupan sosial (Seligman, 2004). Selanjutnya menurut Seligman (2004), orang akan merasa memiliki tingkat subjective well-being yang lebih tinggi ketika waktu yang digunakan untuk bersosialisasi lebih banyak daripada waktu yang digunakan untuk sendirian. Kehidupan sosial masyarakat merupakan suatu sistem interaksi antar individu, antar kelompok, maupun individu dengan kelompok yang dapat dikatakan positif apabila saling menguntungkan (Rachmawati, 2011). Interaksi yang saling menguntungkan tersebut mampu memberikan keuntungan bagi pihak-pihak yang terlibat. Interaksi yang terjadi dalam kehidupan individu yang saling menguntungkan misalnya saling meminta dan memberi pertolongan. Seorang individu akan memberikan bantuan kepada pihak lain yang membutuhkan bantuan, begitu pula sebaliknya. Akan tetapi, pada kenyataannya masih terdapat beberapa pihak yang tidak mendapat bantuan dari pihak lain ketika bantuan tersebut dibutuhkankarena setiap orang memiliki orientasi dalam hidupnya masing-masing. 
Pada tahun 1976, Erich Fromm menyampaikan gagasan mengenai modus eksistensi manusia orientasi 'memiliki' dan orientasi 'menjadi' (1976). Dijelaskan lebih lanjut oleh Fromm (1976) bahwa orientasi 'memiliki' adalah orientasi manusia yang ingin memilikibarang secara material maupun jabatan, sedangkan orientasi 'menjadi' adalah orientasi manusia yang ingin menjadikan dirinya berguna dan memiliki peran positif bagi dirinya maupun orang lain di sekitarnya seperti menolong dan berbagi. Fromm (1976) memberikan lanjutan bahwa manusia yang memiliki orientasi 'menjadi' semakin beralih menuju orientasi 'memiliki' yang ditandai dengan pertimbangan untung dan rugi yang akan diterimanya ketika memberikan bantuan pada pihak lain yang membutuhkan bantuan. Hal tersebut mengakibatkan manusia akan memiliki banyak pertimbangan ketika akan memberikan bantuan kepada orang lain yang membutuhkan bantuan.

Perilaku prososial merupakan segala tindakan yang dapat memberikan keuntungan atau manfaat kepada orang lain (Baron \& Branscombe, 2012; Taufik, 2012; Rahman, 2013; Papalia, 2014). Perilaku prososial merupakan perilaku positif yang mulai terbentuk pada usia kanak-kanak, yaitu sejak usia dua tahun karena dalam usia tersebut kompetensi kognitif dan afektif sudah cukup berkembang (Rahman, 2013). Anak mulai dapat belajar mengenai kepedulian kepada orang lain melalui pemahamannya terhadap perilaku prososial dan perilaku empatik kepada orang lain dan memahaminya sampai ia tumbuh dewasa (Papalia, 2014).

Baron dan Branscombe (2012) mengatakan bahwa tindakan menolong orang lain yang membutuhkan bantuan dapat memberikan perasaan positif dan mengurangi keadaan negatif. Lebih lanjut dinyatakan oleh Baron dan Branscombe (2012) bahwa perasaan positif tersebut didapatkan karena seseorang akan merasa senang jika melihat orang lain senang dan tindakan yang dilakukannya memberikan kontribusi dalam kesenangan orang lain. Selanjutnya Baron dan Branscombe (2012) menjelaskan bahwa perilaku prososial dapat mengurangi perasaan negatif memiliki pengertian bahwa ketika seseorang berada dalam keadaan negatif dan ia membantu orang lain maka muncul kesenangan dari dalam dirinya karena ia akan menganggap dirinya bermanfaat bagi orang lain dan hidupnya menjadi lebih bermakna. Perasaan negatif yang awalnya dirasakan akan berkurang dengan keadaan tersebut.

Hal serupa juga disampaikan oleh Nelson (2015) bahwa orang yang melakukan perilaku prososial yaitu berbagi dengan orang lain akan lebih merasakan perasaan senang jika dibandingkan dengan orang yang menikmati apayang dimilikinya sendiri. Penelitian yang dilakukanoleh Nelson (2015) tersebut menunjukkan bahwa orang yang memiliki tingkat perilaku prososial yang rendah lebih sedikit merasakan perasaan senang dibanding orang yang memiliki tingkat perilaku prososial yang tinggi. Perasaan senang atau perasaan positif merupakan salah satu aspek dalam subjective well-being yang menunjukkan bahwa semakin rendah perasaan positif yang dirasakan maka subjective well-being orang tersebut juga akan semakin rendah (Diener, Oishi, \& Lucas, 2012). Hal tersebut menunjukkan bahwa orang yang memiliki perilaku prososial yang rendah akan berpengaruh pada rendahnya subjective well-being dalam dirinya.

Perilaku prososial merupakan hal penting dan cukup umum dalam kehidupan di sosial (Baron \& Branscombe, 2012). Terdapat sebagian orang yang melakukan perilaku prososial sebagai bentuk kesadaran untuk memberikan bantuan kepada orang lain yang membutuhkan bantuan dan membentuk kegiatan sosial sebagai wadah bagi individu untuk memberikan bantuan kepada orang lain yang membutuhkan bantuan. Salah satu kegiatan sosial tersebut adalah gerakan Indonesia Mengajar.

Indonesia Mengajar merupakan sebuah gerakan untuk ikut mencerdaskan kehidupan bangsa yang berdiri sejak tahun 2006 (Anonim, 2018). Indonesia Mengajar memiliki visi untuk mengajak semua pihak 
untuk ambil bagian memajukan pendidikan di Indonesia, sedangkan misinya yaitu mendorong terciptanya dampak yang berkelanjutan di daerah entitas sasaran, membangun jejaring pemimpin masa depan yang memiliki pemahaman akar rumput, serta mendorong tumbuhnya gerakan sosial pendidikan di Indonesia (Anonim, 2018).

Indonesia Mengajar bergerak di bidang pendidikan yang merekrut, melatih, dan mengirimkan lulusan terbaik untuk mengajar sekolah dasar di daerah pelosok Indonesia selama1 tahun (Anonim, 2018). Masyarakat yang mendaftarkan diri untuk menjadi bagian dari Indonesia Mengajar memiliki peluang kurang dari 1\% dari belasan ribu orang yang mendaftar (Anonim, 2018). Para pengajar muda akan ditempatkan di lokasi sasaran yang membutuhkan perbaikan pendidikan. Selain para pengajar muda, terdapat para sukarelawan yang tergabung dalam gerakan Indonesia Mengajar yang turut menunjang kegiatan-kegiatan untuk memajukan pendidikan di Indonesia, salah satunya yaitu Kelas Inspirasi.

Kelas Inspirasi merupakan gerakan para profesional turun ke Sekolah Dasar (SD) selama satu hari, berbagi cerita dan pengalaman kerja dan motivasi untuk meraih cita-cita (Anonim, 2019). Sukarelawan yang memberikan inspirasi tersebut melaksanakan cuti kerja secara serempak pada hariinspirasi yang telah ditentukan tanpa mendapatkan imbalan material. Sukarelawan tersebut merelakan untuk cuti bekerja untuk mengikuti kegiatan Kelas Inspirasi.

Berdasarkan hasil wawancara dengan salah satu sukarelawan Kelas Inspirasi Yogyakartadiperoleh informasi bahwa Kelas Inspirasi tersebar di beberapa wilayah di Indonesia. Sukarelawan tersebut menjelaskan lebih lanjut bahwa dalam satu wilayah terdapat kepanitiaan lokal yang berfokus pada kegiatan Kelas Inspirasi di wilayah tersebut. Setiap wilayah memiliki tujuanyang sama mengenai tujuan kegiatan Kelas Inspirasi. Salah satu wilayah tersebut yaitu Kelas Inspirasi Yogyakarta. Sukarelawan Kelas Inspirasi Yogyakarta melakukan kegiatan di berbagai wilayah di Daerah
Istimewa Yogyakarta.

Sukarelawan meluangkan waktunya untuk memberikan manfaat kepada pihak lain yang membutuhkan perbaikan pendidikan. Fenomena ini dapat dikatakan sebagai salah satu bentuk perilaku prososial karena sukarelawan memberikan bantuan atau manfaat kepada orang lain (Baron \& Branscombe, 2012; Taufik, 2012; Rahman, 2013; Papalia, 2014). Kegiatan yang dilakukan sukarelawan Kelas Inspirasi Yogyakarta tersebut seperti menjadi inspirator, mendokumentasikan kegiatan, atau sebagai panitia pelaksanaan kegiatan. Sukarelawan Kelas Inspirasi Yogyakarta melakukan kegiatan-kegiatan tersebut tanpa menerima imbalan langsung, bahkan mereka mengorbankan waktu yang dimilikinya untuk turut berpartisipasi dalam kegiatan tersebut.

Salah satu cara yang dapat dilakukan untuk meningkatkan subjective well-being yang rendah yaitu dengan meningkatkan perilaku prososial. Perilaku prososial yang tinggi dapat menunjukkan subjective well-being yang tinggi pula. Penelitian sebelumnya mengenai permasalahan ini juga belum banyak dilakukan, sehingga penelitian ini dirasa penting untuk dilakukan. Berdasarkan fenomena Kelas Inspirasi dan kerangka konseptual yang telah dijelaskan sebelumnya, peneliti tertarik untuk membuktikan perilaku prososial sebagai prediktor subjective well-being pada sukarelawan.

\section{Metode Penelitian}

\section{Jenis Penelitian}

Penelitian ini menggunakan pendekatan kuantitatif dengan jenis korelasional.

\section{Waktu dan Tempat Penelitian}

Penelitian ini dilakukan pada bulan Januari sampai bulan Maret 2019. Penelitian dilaksanakan di Kelas Inspirasi Yogyakarta.

\section{Populasi dan Sampel Penelitian}

Populasi penelitian ini adalah sukarelawan Kelas Inspirasi Yogyakarta. 
Sampel pada penelitian ini berjumlah 1002. orang. Pengambilan sampel menggunakan teknik accidental sampling.

\section{Teknik dan Instrumen Pengumpulan Data}

Pengumpulan data pada penelitian ini menggunakan pengukuran dengan teknik kuesioner. Instrumen pengumpulan data yang digunakan berbentuk skala yang terdiri atas skala perilaku prososial dan skala subjective well-being.

Empat aspek perilaku prososial yaitu aspek bekerja sama, menolong, berbagi, dan menyumbang menunjukkan tingkat perilaku pada seorang individu. Individu yang memiliki perilaku prososial yang tinggi ditandai dengan tingginya sikap yang menunjukkan aspek bekerja sama, menolong, berbagi, dan menyumbang. Subjective well-being ditunjukkan oleh tigaaspek, yaitu aspek afek positif, afek negatif, dan kepuasan hidup. Individu yang memiliki tingkat subjective well-being yang tinggi ditunjukkan oleh tingginya afek positif, rendahnya afek negatif, serta tingginya kepuasan hidup.

\section{Teknik Analisis Data}

Teknik analisis data yang digunakan dalam penelitian ini terdiri atas analisis deskriptif, uji prasyarat analisis yang terdiri dari uji normalitas dan uji linearitas, serta uji hipotesis.

1. Analisis Deksriptif

Data yang berupa skala terdiri dari empat pilihan dengan skor masing-masing, yaitu (4) = sangat sesuai, (3) = sesuai, (2) = tidak sesuai, dan (1) = sangat tidak sesuai. Jumlah skor dari keseluruhan butir akan dikategorikan ke dalam lima kategori. Pengkategorian dilakukan dengan menggunakan perhitungan manual.

Tabel 1. Norma Kategorisasi Azwar (2012)

\begin{tabular}{ll}
\hline Kategori & \multicolumn{1}{c}{ Rumus } \\
\hline Sangat Rendah & $\mathrm{X} \leq \mu-1.5 \sigma$ \\
\hline Rendah & $\mu-0.5 \sigma<\mathrm{X} \leq \mu-1.5 \sigma$ \\
\hline Sedang & $\mu-0.5 \sigma<\mathrm{X} \leq \mu+0.5 \sigma$ \\
\hline Tinggi & $\mu+1.5 \sigma<\mathrm{X} \leq \mu+0.5 \sigma$ \\
\hline Sangat Tinggi & $\mathrm{X}>\mu+1.5 \sigma$
\end{tabular}

a. Uji Normalitas

Uji normalitas digunakan untuk mengetahui data dalam penelitian berdistribusi normal atau tidak. Penelitian ini menggunakan uji normalitas One Sample Kolmogorov Smirnov dengan bantuan program komputer SPSS for Windows. Pengujian ini dilakukan pada nilai residual dari Y, yaitu selisih dari $Y$ yang merupakan hasil pengamatan dan $\mathrm{Y}$ prediksi yang berdasarkan persamaan regresi. Hasil yang menunjukkan nilai signifikansi lebih besar dari 0.05 menunjukkan bahwa data berdistribusi normal, sebaliknya apabila nilai signifikansi lebih kecil dari 0.05 maka data tidak berdistribusi normal.

b. Uji Linearitas

Uji linearitas digunakan untuk mengetahui apakah variabel prediktor dan variabel kriterium memiliki hubungan linear atautidak. Dua variabel dikatakan linear apabila nilai signifikansi menunjukkan angka di atas 0.05. Penghitungan uji linearitas pada penelitian ini menggunakan bantuan program komputer SPSS for Windows.

3. Uji Hipotesis

Penguijan hipotesis dilakukan setelah data penelitian dianalisis dan memenuhi uji persyaratan analisis. Pengujian hipotesis dalam penelitian ini menggunakan regresi sederhana dengan bantuan program komputer SPSS for Windows. Uji regresi sederhana dilakukan untuk mengetahui pengaruh satu variabel prediktor terhadap satu variabel kriterium. Uji regresi sederhana dipilih karena dalam penelitian ini terdiri dari satu variabel prediktor $(\mathrm{X})$ dan satuvariabel kriterium (Y). Untuk mencari persamaan garis regresi linear sederhana menggunakan rumus $\mathrm{Y}=\mathrm{a}+\mathrm{b} . \mathrm{X}$. 


\section{Hasil Penelitian dan Pembahasan}

Data penelitian diperoleh dari 100 sukarelawan di Kelas Inspirasi Yogyakarta. Data dikumpulkan menggunakan skala perilaku prososial dan skala subjective wellbeing. Analisis deskriptif dihitung dengan penghitungan manual berdasarkan norma kategorisasi

Tabel 2. Kategorisasi Perilaku Prososial

\begin{tabular}{llc}
\hline Kategori & Rumus penentuan & Persentase \\
\hline Sangat & $\mathrm{X} \leq 103,4$ & $9 \%$ \\
Rendah & & \\
Rendah & $103,4<\mathrm{X} \leq 116,4$ & $19 \%$ \\
Sedang & $116,4<\mathrm{X} \leq 129,4$ & $35 \%$ \\
Tinggi & $129,4<\mathrm{X} \leq 142,3$ & $36 \%$ \\
Sangat & $\mathrm{X}>142,3$ & $1 \%$ \\
Tinggi & & \\
\hline & Total & $100 \%$ \\
\hline
\end{tabular}

Berdasarkan Tabel 2. diketahui bahwa frekuensi paling banyak berada pada kategoritinggi (129.405 $<\mathrm{X} \leq 142.395)$ dengan jumlah sebanyak 36 sukarelawan $(36 \%)$. Frekuensi palingsedikit berada pada kategori sangat tinggi $(X>142.395)$ dengan jumlah sebanyak 1 sukarelawan $(1 \%)$.

Tabel 3. Kategorisasi Subjective well-being

\begin{tabular}{llc}
\hline Kategori & Rumus penentuan & Persentase \\
\hline Sangat & $\mathrm{X} \leq 121$ & $6 \%$ \\
Rendah & & \\
Rendah & $121<\mathrm{X} \leq 136.9$ & $28 \%$ \\
Sedang & $136.9<\mathrm{X} \leq 152.8$ & $31 \%$ \\
Tinggi & $152.8<\mathrm{X} \leq 168.7$ & $28 \%$ \\
Sangat & $\mathrm{X}>168.7$ & $7 \%$ \\
Tinggi & & \\
\hline \multicolumn{2}{c}{ Total } & $100 \%$ \\
\hline
\end{tabular}

Berdasarkan Tabel 3 diketahui bahwafrekuensi paling banyak berada pada kategori sedang $(136.9<\mathrm{X} \leq 152.8)$ dengan jumlah sebanyak 31 sukarelawan (31\%). Frekuensi paling sedikit berada pada kategori sangat rendah $(\mathrm{X} \leq 121)$ dengan jumlah sebanyak 6 sukarelawan $(6 \%)$.

Uji persyaratan analisis dalam penelitian ini menggunakan uji normalitas dan uji linearitas. Uji normalitas menunjukkan nilai signifikansi sebesar $0.120>0.05$ sedangkan uji linearitas menunjukkan nilai signifikansi $0.475>0.05$. Uji hipotesis dalam penelitian ini menggunakan analisis regresi linear sederhana. Hasil uji statistik F menunjukkan nilai $\mathrm{F}$ hitung sebesar 58.065 dengan probabilitas nilai sig. $0.001<\alpha(0.05)$ yang berarti variabel $\mathrm{X}$ dapat memprediksi variabel $\mathrm{Y}$. Koefisien determinasi $\mathrm{R}$ square menunjukkan hasil 0.372 yang berarti sumbangan efektif variabel $\mathrm{X}$ terhadap variabel Y sebesar 37\%.

Analisis data penelitian ini menunjukkan bahwa perilaku prososial dapat menjadi prediktor subjective well-being pada sukarelawan di Kelas Inspirasi Yogyakarta. Hal ini berarti hipotesis yang berbunyi perilaku prososial mampu memprediksi subjective wellbeing pada sukarelawan terbukti. Subjective wellbeing merupakan hasil evaluasi kognitif dan afektif seseorang terhadap kehidupan yang dijalaninya yang terdiri atas aspek afek positif, afek negatif, serta kepuasan hidup (Diener, Oishi, \& Lucas, 2012). Menurut Baron \& Branscombe (2012) perilaku prososial dapat meningkatkan afek positif dan mengurangiafek negatif bagi pelakunya. Hal ini sesuai dengan perilaku prososial yang ditunjukkan oleh sukarelawan Kelas Inspirasi Yogyakarta.

Perilaku prososial merupakan tindakan sukarela untuk membantu atau memberikan manfaat kepada individu atau kelompok individu lain (Eisenberg \& Mussen, 1989). Perilaku prososial terdiri atas aspek bekerja sama, menolong, berbagi, serta berderma (Staub dalam Andelia \& Noor, 2014). Sukarelawan menunjukkan perilaku bekerja sama yaitu dengan adanya kerja sama yang dilakukan antar sukarelawan maupun dengan pihak lain dalam melaksanakan kegiatan di Kelas Inspirasi Yogyakarta. Perilaku menolong ditunjukkan dengan sikap yang mereka ambil untukmemberikan bantuan kepada orang lain yang membutuhkan, yaitu mendatangi para siswa Sekolah Dasar untuk melakukan kegiatan bersama. Di sekolah yang dikunjungi tersebut, sukarelawan akan berbagi cerita dan pengalaman mengenai 
profesi yang mereka miliki saat ini. Sukarelawan juga memberikan sebagian uang yang dimilikinya secara sukarela untuk pelaksanaan kegiatan agar kegiatan dapat berjalan dengan lancar.

Sukarelawan Kelas Inspirasi Yogyakarta berbagi cerita dan pengalaman mengenai profesi mereka kepada siswa Sekolah Dasar yang dikunjunginya. Siswa tersebut akan mengetahui gambaran mengenai profesi yang disampaikan sukarelawan kemudian memiliki gambaran mengenai cita-cita profesi di masa depannya.Sukarelawan memiliki kontribusi dalam mengenalkan profesi-profesi yang disampaikan kepada para siswa. Kontribusi yang diberikan sukarelawan tersebut membuat sukarelawan memiliki peran yang positif dalam kehidupan orang lain. $\mathrm{Hal}$ tersebut memunculkan afek positif bagi sukarelawan karena mereka dapat memberikan bantuan atau manfaat kepada para siswa. Hal ini sesuai dengan pernyataan Baron dan Branscombe (2012) yang menyatakan bahwa perilaku prososial dapat meningkatkan afek positif pelakunya.

Sukarelawan menunjukkan perilaku menolong dilihat dari keterlibatan mereka dalam memberikan bantuan kepada siswa Sekolah Dasar untuk mengenal dunia profesi. Perilaku menolong yang ditunjukkan oleh sukarelawan tersebut mampu memunculkan perasaan positif bagi sukarelawan. Hal ini sesuai dengan Sheilamona (2017) yang mengatakan bahwa menolong dapat dianggap sebagai salah satu cara yang dapat membuat perasaan lebih baik.

Sheilamona (2017) menyatakan bahwa menolong dapat menghilangkan emosi negatif didalam diri pelakunya. Afek negatif yang dirasakan sukarelawan akan berkurang ketika melakukan kegiatan bersama dengan siswa Sekolah Dasar yang dikunjunginya. Afek negatif tersebut berkurang karena digantikan dengan afek positif yang muncul saat melakukan kegiatan bersama- sama dengan suasana yang menyenangkan. Hal ini sesuai dengan pendapat Baron dan Branscombe (2012) yang menyatakan bahwa perilaku prososial dapat mengurangi afek negatif pelakunya.

Perilaku prososial atau aktivitas yang menyenangkan dapat mempengaruhi kepuasandalam hidup pelakunya (Hutapea \& Dewi, 2012). Hal ini dapat dilihat pada sukarelawan yang melakukan perilaku prososial yang mengikutikegiatan lebih dari satu kali. Hal tersebut dilakukan karena melalui kegiatan kerelawanannya tersebut sukarelawan mengetahui bahwa siswa Sekolah Dasar yang dikunjunginya memiliki keinginan untuk menjadi seperti mereka di masa depannya kelak. Kepuasan hidup sukarelawan akan meningkat karena terdapat orang lain yang berkeinginan untuk menjadi seperti mereka.

Individu yang melakukan perilaku prososial akan cenderung memiliki afek positif yang tinggi dan afek negatif yang rendah (Baron \& Branscombe, 2012). Perilaku prososial juga dapat meningkatkan kepuasan hidup seorang individu karena pencapaian saat ini dapat menginspirasi orang lain. Sukarelawan pada Kelas Inspirasi Yogyakarta memiliki tingkat perilaku prososial yang tinggi. Afek positif yang dimiliki sukarelawan berada dalam kategori sedang, sedangkan afek negatif yang dirasakan sukarelawan berada dalam kategori rendah. Hal ini dapat dikatakan bahwa sukarelawan lebih sering merasakan afek positif daripada merasakan afek negatif. Kepuasan hidup sukarelawan berada dalam kategori sedang. Hal ini menunjukkan bahwa sukarelawan merasa cukup puas dengan kehidupannya.

Hasil analisis data dalam penelitian ini menunjukkan bahwa variabel perilaku prososial mampu memprediksi variabel subjective well-being dengan nilai kontribusi sebesar 37\%. Selebihnya dipengaruhi faktor lain sebesar $63 \%$ yang tidak diteliti dalam penelitian ini. Hal ini berarti bahwa terdapat pengaruh perilaku prososial terhadap subjective well-being pada sukarelawan. Dengan demikian, dapat dikatakan bahwa salah satu hal yang dapat dilakukan oleh sukarelawan untuk meningkatkan subjective well-being adalah dengan meningkatkan perilaku prososialnya. 
Berdasarkan hasil penelitian ini diketahui bahwa terdapat 63\% faktor lain yang dapat mempengaruhi subjective well-being selain perilaku prososial. Hal ini dikarenakan perilaku prososial bukan satu-satunya faktor yang mempengaruhi subjective well-being. Terdapat faktor lain yang dapatmempengaruhi subjective well-being seperti faktor internal yang terdiri dari pengalaman masa lalu, masa sekarang, dan masa depan, serta faktor eksternal yang terdiri dari uang, pernikahan, emosi, usia, kesehatan, agama, pendidikan, iklim, ras, dan gender (Seligman, 2004).

Hasil analisis data menunjukkan bahwa sukarelawan menunjukkan aspek bekerja sama dan aspek menolong dalam kategori sedang. Hasil ini kurang sesuai dengan penelitian yang dilakukan Sheilamona (2017) yang menyatakan bahwasukarelawan menunjukkan perilaku bekerja sama yang tinggi yang dilihat dari tingginya frekuensi perilaku prososial. Ketidaksesuaian ini dikarenakan frekuensi kegiatan yang dilakukan oleh sukarelawan Kelas Inspirasi Yogyakarta hanya dilakukan satu kali dalam satu tahun. Aspek berbagi dan aspek menyumbang ditunjukkan dalam kategori yang tinggi. Sukarelawan berbagi pengalaman yang dimilikinya kepada siswa di Sekolah Dasar yang dikunjungi. Biaya yang dikeluarkan untuk kebutuhan selama kegiatan diperoleh dari sukarelawan yang menyumbangkan iuran yang bersifat sukarela. Hasil ini sesuai dengan pernyataan bahwa perilaku prososial yang tinggi ditunjukkan dengan tingginya perilaku berbagi dan menyumbang (Andelia \& Noor, 2014).

Aspek afek positif dan aspek kepuasan hidup yang dimiliki oleh sukarelawan berada dalam kategori sedang. Aspek afek negatif yang dirasakan sukarelawan berada dalam kategori rendah yang ditunjukkan pada tingginya ketiadaan afek negatif yang dirasakan. Selama kegiatan berlangsung, siswa merasa senang dengan kedatangan sukarelawan yang berbagi cerita dan pengalaman kepada mereka. Afek negatif yang dirasakan sukarelawan akan berkurang melihat antusiasme dan kegembiraan yang ditunjukkan oleh siswa Sekolah Dasar yang dikunjungi. Hal ini menunjukkan bahwa perilaku prososial yang dilakukan oleh sukarelawan dapat mengurangi afek negatif yang dirasakannya (Baron \& Branscombe, 2012).

\section{Simpulan dan Saran}

\section{Simpulan}

Berdasarkan penelitian yang sudah dilakukan, dapat diambil kesimpulan bahwa perilaku prososial dapat menjadi prediktor subjective well-being pada sukarelawan Kelas Inspirasi Yogyakarta. Hal ini berarti bahwa apabila diketahui perilaku prososial seseorang berada dalam kategori tinggi, maka dapat diprediksi bahwa subjective well-being orang tersebut juga cenderung tinggi. Apabila diketahui perilaku prososial seseorang berada dalam kategori rendah, maka dapat diprediksi bahwa subjective well-being orang tersebut juga cenderung rendah.

Saran

Berdasarkan kesimpulan dari penelitian yang sudah dilakukan, maka saran yang dapat diberikan yaitu sebagai berikut:

1. Bagi sukarelawan dan pihak lain yang terlibat dalam kegiatan Kelas Inspirasi Yogyakarta, perilaku prososial yang sudah berada pada kategori tinggi yaitu aspek berbagi dan aspek menyumbang harus dipertahankan dengan terus mengikuti kegiatan yang berhubungan dengan perilaku prososial. Aspek perilaku prososial yang berada pada kategori sedang yaitu aspek bekerja sama dan aspek menolong perlu ditingkatkan lagi. Dalam hal ini butuh kesadaran diri dan pihak lain yang membantu peningkatan perilaku prososial seperti keikutsertaan dalam organisasimaupun perkumpulan yang melibatkan perilaku kerja sama dan tolong menolong. Hasil penelitian ini dapat dijadikan bahan evaluasi dan introspeksi diri.

2. Bagi penelitian lain, diperlukan penelitian selanjutnya mengenai 
variabel perilaku prososial maupun subjective well-being yang memiliki jumlah sampel lebih banyak dan cakupan generalisasi yang lebih luas

\section{Daftar Pustaka}

Andelia, B. \& Noor, H. (2014). Hubungan religiusitas dengan perilaku prososial pada relawan korsa. Jurnal Prosiding Psikologi. ISSN: 2460-6448.

Anic, P., \& Toncic, M. (2013). Orientation to happiness, subjective well-being and life goals. Psychological Topics, 22(1), 135153.

Anonim. (2018). Sepuluh kebiasaan buruk orang yang tak bahagia. CNN Indonesia. Diakses dari https://www.cnnindonesia.com /gaya- hidup/20160727140746255-

$147387 /$ sepuluh-kebiasaanburuk-orang- yang-tak-bahagia

Anonim. (2018) Finlandia negara paling bahagia, Indonesia peringkat 96 dari 156 negara. BBC News Indonesia. Diakses dari https://www.bbc.com/indonesi a/majalah-43422986

Anonim. (2018). Kenali kelasinspirasi. Kelas Inspirasi. Diakses dari http://kelasinspirasi.org/tentan gki

Anonim. (2019) Tentang kelasinspirasi. Kelas Inspirasi Yogyakarta. Diakses dari https://kelasinspirasiyogyakarta .org/tenta ng-ki/

Azwar, S. (2012). Penyusunan skala psikologi. Yogyakarta: Pustaka Pelajar.
Baron, R. A., Branscombe, N. R. (2012). Sosial psychology $13^{\text {th }}$ ed. USA: Pearson Education, Inc.

Diener, E., Oishi, S., \& Lucas, R. E. (2012). Subjective well-being: the science of happiness and life satisfaction. In the oxfordhandbook of positive psychology. OxfordUniversity Press.

Eisenberg, N. \& Mussen, P. H. (1989). The roots of prosocial behavior in cbildren. Cambridge, US: Cambridge University Press.

Fakhitah, H., \& Djamhoer, T. D. (2015). Kesejahteraan psikologis pada survivorkanker di Bandung Cancer Society (BCS). Prosiding psikologi, ISSN: 2460-6448.

Fromm, E. (1976). To bave or to be?. New York: Continuum.

Hutapea, B., \& Dewi, F. I. R. (2012). Peran kebermaknaan hidup dan kepemimpinanmelayani terhadap kepuasan hidup sukarelawan Lembaga swadaya masyarakat. Insan, 14(03).

Lomas, T., Hefferon, K., Ivtzan, I. (2016). Positive developmental psychology: a review of literature concerning well-being throughout the lifespan. The Journal ofHappiness \& Well-Being. 4(1), 143-164.

Nelson, S. K. (2015). The effects of prosocial and self- focused behaviors on psychological flourishing (Disertation). California Digital Library: University of California.

Papalia, D. E. (2014). Menyelami perkembangan manusia. Jakarta: Salemba Humanika.

Rachmawati, E., Muntasib, H., dan Sunkar, A. (2011). Interaksi sosial masyarakat 
dalam pengembangan wisata alam di kawasan gunung salak endah. Jurnal Forum Pascasarjana, 34(1), 23-32.

Rahman, A. A. (2013). Psikologi sosial: integrasi pengetabuan wabyu dan pengetahuan empirik. Depok: PT Raja Grafindo Persada.

Ramadhani, T., Djunaedi, \& Sismiati, A. (2016). Kesejahteraan psikologis (psychological well-being) siswa yang orang tuanya bercerai (Studi deskriptif yang dilakukan pada siswa di SMK negeri 26 pembangunan Jakarta). Insight: Jurnal Bimbingan Konseling, 5(1).

Santrock, J. W. (2013). Life span development fourteenth edition. New York: The McGraw- Hill Companies.

Seligman, M. E.P. (2004). Authentic happiness: using the new positive psychology to realize your potentials for lasting fullfillment. Free Press.

Sheilamona, A. (2017). Perilaku prososial pada relawan donor darah aktif di pmi solo. Skripsi

Taufik. (2012). Empati: pendekatan psikologi sosial. Depok: PT RajaGrafindo Persada. 